\title{
Traditionalism at Universities, Colleges and in Practice: Urbanism, Architecture, Sculpture, Ornament, Painting and Design
}

\section{Tradicionalismus na vysokých školách a v praxi: urbanismus, architektura, sochařství, ornament, maliřství a design}

\author{
Emil Adamec \\ Ústav teorie architektury, Fakulta architektury, Vysoké učení technické v Brně \\ školitel: doc. PhDr. Martin Horáček, Ph.D.
}

\begin{abstract}
Traditionalism combines urbanism, architecture, sculpture, ornament, painting, and design into one complex. According to statistics, the public favours traditional architecture and urbanism. Traditional design, computer technology, a scientific approach to theory, ornament in architecture, and scaling in urbanism are the proposed solutions here. Vitruvius, Palladio, Camillo Sitte, Léon Krier, Roger Scruton or Nikos A. Salingaros, medieval cities, and imperial or New Urbanism offer sustainability, and quality design. In heritage conservation, traditionalism provides an alternative to the Venice Charter and the Athens Charter. Accredited schools of architecture, art and design will be asked whether traditionalism is being taught at their institutions. Workshops and courses in traditionalism for students might support a specialized field of study, interdisciplinary cooperation and exchange between schools. Keeping local traditions is important for human existence, cultural maturity and a healthy lifestyle.
\end{abstract}

KEYWORDS: traditionalism; urbanism; architecture; sculpture; ornament; design

\begin{abstract}
ABSTRAKT: Tradicionalismus spojuje urbanismus, architekturu, sochařství, ornament, malírství a design $\mathrm{v}$ jeden celek. Podle statistik veřejnost upřednostňuje tradiční architekturu a urbanismus. Navrhovanými řešeními jsou tradiční navrhování, počítačová technologie, vědecký př́stup v teorii, ornament $\mathrm{v}$ architektuře nebo odstupňovaná měřítka v urbanismu. Vitruvius, Palladio, Camillo Sitte, Léon Krier, Roger Scruton nebo Nikos A. Salingaros, středověká města a císařský nebo Nový urbanismus nabízejí udržitelnost a kvalitní design. Tradicionalismus v památkové péči představuje alternativu Benátské charty nebo Aténské charty. Akreditované školy architektury, umění a designu budou požádány, aby odpověděly na to, zda se tradici-
\end{abstract}


onalismus vyučuje v jejich institucích. Workshopy a vyučovaný předmět tradicionalismus pro studenty mohou nabídnout otevření samostatného oboru, mezioborovou spolupráci a výměnu mezi školami. Udržování místních tradic je důležité pro lidskou existenci, kulturní vyspělost a zdravý způsob života.

KLÍČOVÁ SLOVA: tradicionalismus; urbanismus; architektura; sochařství; ornament; design

\section{Úvod}

Cílem tohoto př́spěvku je obhajoba tradicionalismu, jeho estetických kvalit, dlouhodobé udržitelnosti a prospěšnosti pro zdraví. Nabízeným řešením strohosti modernismu nebo problému smíšené ulice může být Nový urbanismus, vrstvený urbanismus a tradicionalismus na školách a ve stavební praxi, dle tradice beaux-arts. Veřejností upřednostňovaná tradiční architektura a pěší ulice jsou v kontrastu s výukou na školách a architektonickou produkcí (výškové a parametricky modelované budovy, město pro automobily atd.). Ani pasivní domy nejsou dlouhodobě udržitelné, včetně zdravotních rizik s nimi spojených (Hasselaar R., 2008). Je patrná absence ornamentu v architektuře. Počítačové aplikace pro architekty nejsou přizpůsobeny tradicionalistickému navrhování (absence nadstaveb, knihoven s tradicionalistickými stavebními detaily a propojením mezi aplikacemi atp.). Je navrženo spojení architektury s ornamentem, staveb zdravých, př́ijemných, krásných a trvanlivých. Tradicionalismus na školách (beaux-arts) spojuje oddělené disciplíny, včetně zařazení digitálních postupů. Tradicionalismus na školách kromě výuky řádu a slohu nabízí v teorii architektury i zastoupení vědy (Salingaros N. A., 2017). Tradicionalismus na vysokých školách je alternativou k modernismu jako regulérní, plnohodnotný směr umělecké disciplíny. Je založen na principech směru beaux-arts (Egbert D. D., 1980), jehož atributy jsou klasický řád a vysoká umělecká hodnota, na rozdíl od modernismu, kde ve skutečnosti (nehledě na teorii) př̌evládá povrchnost a odcizení (Scruton R., 2013). Minulé modernistické století nemusí nutně být dogmatem i pro současnou a budoucí architektonickou tvorbu. Pokračování v předchozí tisícileté tradici architektury není anachronismus. Tradicionalismus je logickým a dlouhodobě udržitelným řešením (Krier L., 1998). Tradiční stavby jsou ověřené staletími. Biologická a duchovní podstata člověka není přizpůsobena modernismu. Je vědecky dokázáno, že pobyt ve strohém a nekomplexním moderním prostředí má negativní dopady na zdraví člověka a celé společnosti. Urbanismus, architektura, umění a design každodenně ovlivňují naše životy a zdraví. Moderní výstavba, vytržená z kontextu 
přírodního prostředí, postrádá pozitivní energii (Salingaros N. A., 2017). Povrchová automobilová doprava ve městech úplně změnila zkušenost $\mathrm{z}$ ulice a význam chodců. Namísto př́ijemného zážitku z pobytu na ulici je chodec nucen neustále sledovat všudypř́itomnou automobilovou dopravu (dopravní provoz, hluk, exhalace, př̌ekážející parkující automobily atd.). Ani situace a výuka v současném urbanismu nejsou dostatečně uspokojivé. Koncept smíšené ulice, kde chodci, cyklisti, tramvaje a automobily sdílejí jednu ulici, je rušivý a nemůže uspokojovat nikoho. Předchozí „inovace“ dopravní sítě, tj. rozšíření a narovnání silnic a ulic a solitérní kompozice výškových staveb bez přihlédnutí $\mathrm{k}$ uměleckým zásadám, změnily moderní města na neobyvatelná. (Sitte C., 2012). Nový urbanismus, založený na tradičním navrhování, nabízí dlouhodobé řešení, které vytváří prúijemné a lidské prostředí a současně řeší problémy způsobené nevhodným parcelováním a zónováním měst (Krier L., 1998). Vrstvený urbanismus počítá s rozvojem měst nikoli do výšky, tj. solitérní nebo panelovou výstavbou, ale do systému hustých pěších ulic, kde veškerá automobilová doprava je vedena pod zemským povrchem. Po povrchu by kromě chodců pouze jezdily tramvaje, cyklisté a taxislužba využívající elektrické automobily. V nouzových př́ípadech běžná vozidla policie, záchranné a požární služby.

\section{Zhodnocení současného stavu}

Současné modernistické směřování výtvarných škol je poznamenáno rozdělením jednotlivých oborů, které spolu málo komunikují. Umělecké artefakty se umístují do galerií namísto toho, aby byly součástí architektury a urbanismu. Ani spojení modernistické architektury s uměním není ideální. Výsledkem se stává chaos, strohost, sterilita. Ve srovnání s kvalitními tradicionalistickými figurálními sochami působí moderní, konceptuální umělecká díla v prostoru ulice rušivě nebo banálně. Překvapivě se tradicionalismus nevyučuje téměř na žádných státních školách, i když statistiky potvrzují, že veřejnost upřednostňuje tradiční budovy před moderními (Adam R., 2009). Na školách architektury jsou naopak tendence k navrhování výškových budov a trend parametrického modelování v architektuře, tj. modelování za použití nástrojů Rhino a Grasshopper (Schnabel M. A., 2007), nebo se testuje architektura, která se jakoby stává sochou (Goldberger P., 2015). Jakkoli tato idea může znít sympaticky, výstupy tak uspokojivé nejsou. Architektura samotná totiž nemůže suplovat absenci sochy a ornamentu v architektuře (Moussavi F., 2006). Parametrický design je v původní tradiční zástavbě cizím prvkem. Chybí přirozený řád, sloh, symetrie, odstupňovaná měŕítka nebo fraktály (Salingaros N. A., 2017). Moderní stavební tendence v arabském světě nebo východní Asii nemusí být vhodné pro Evropu, kde jsou jiné prostorové, kulturní a historické skutečnosti. Projekt rozsáhlého parametrického komplexu v centru Prahy je toho př́íladem (Bečková K., 2016). Pasivní a nulové domy také nejsou zárukou udržitelnosti. Tyto projekty vedou ke konstrukcím s nevyhnutelnou závislostí na dovážených technologiích a elektřině, které jsou 
z dlouhodobého hlediska neudržitelné. Pasivní domy jsou též spojovány se zdravotními riziky (Hasselaar R., 2008). Na základě Benátské charty a Aténské charty jsou moderní ocelové, betonové a skleněné prvky začleňovány do původních tradičních budov, což z estetického a morálního hlediska nemá smysl (Hardy M., 2009). Obnova historických budov v tradičním stylu je zdaleka nejlepším řešením. Již dávno neplatí, že v tradičním navrhování musí být používány pouze tradiční designérské techniky, tj. kresba, malba, ruční modelování. Počítačové aplikace jako Revit (Aubin P., 2013), Archicad (Graphisoft, 2011), Rhinoceros (Congdon R., 2015), Solidworks (FastBrick Robotics, 2018), Vectorworks (O'Skea S., 2013), SketchUp (Heuman F., Lyhagen A., 2015) a Autocad (CAD Blocks, 2018) lze přizpůsobit tradicionalistickému navrhování. Aplikace navíc mohou být rozšířeny prostřednictvím nadstaveb, knihoven a propojení s dalšími aplikacemi, jako jsou ZBrush (Holmes S., 2018), 3DCoat, Cinema 4D. Ovšem nejvhodnějším řešením je vytvoření aplikace pro klasický design - Clasicad.

\section{Navrhované řešení}

Tradicionalismus kromě klasického řádu a symetrie spojuje architekturu s ornamentem. Výsledné stavby jsou zdravé, př́ijemné a krásné. Jsou také velmi trvanlivé, protože vydrží odolávat př́rodním elementům po mnoho staletí (Watkin D., 2006). Výuka tradicionalismu na vysokých školách spojuje oddělené disciplíny jako urbanismus, architektura, sochařství, ornament (Weil C., Weil T., 2009), malírství, design a umělecké řemeslo do jednoho oboru. Kombinované navrhování od fyzické formy za použití kresby, akvarelu či modelování ze sádry k formě digitální za použití 3D skenování, aplikací ZBrush, 3D Coat, Cinema 4D, Rhinoceros nebo CAD, 3D tisku a CNC a zpět $\mathrm{k}$ fyzické formě ručním dokončením detailů a ornamentu v architektuře zaručuje komplexitu a soudobé řešení. Vědecká metoda v teorii architektury obhajuje potřebu tradicionalismu. Je vědecky dokázáno, že pobyt v komplexním prostředí má pozitivní zdravotní účinky na lidské zdraví. Tradiční stavby, ornament a fraktály jsou pro zdravou architekturu nezbytné (Salingaros N. A., 2017). Ve výuce by si studenti architektury vyzkoušeli současné tradicionalistické postupy (Horáček M., 2013). Podobně probíhá výuka např́klad na Škole architektury Notredameské univerzity v USA. Smyslem výuky je posílení znalostí v oblasti současných tradicionalistických uměleckých směrů. Studenti se seznamují s principy tradicionalismu a soudobých designérských postupů v modelaci tradičních architektonických a sochařských prvků. Porovnávají též rozdíly mezi tradicionalismem a modernismem. Učí se řád, sloh, ornament a symetrii dle principů beaux-arts (Naylor G., 1980). Zároveň učí se práci s digitálními technologiemi, skenování objektů, digitálnímu sochařství (Frischer B., 2012) a počítačovému modelování. Ve výuce v českém prostředí by studenti mohli nakonec navrhnout tradicionalistickou budovu na místě, kde v současnosti stojí moderní stavba. Návrh by převedli do akvarelových kreseb, fyzického a digitálního modelu a technických výkresů. 


\section{Závěr}

Zásady tradicionalismu jsou plně použitelné i pro dnešní dobu. Považovat tradicionalismus za staromilství, anachronismus nebo imitaci, které v současnosti nemají co nabídnout, je mylné (Smith G. S., Terry F., 2012). Počátky definování kvalitní architektury najdeme již u Vitruvia (Rowland I. D., Howe T. N., 2001) a později u Palladia (Palladio A., 2002). Jejich teorie byly úspěšně aplikovány architekty v mnoha generacích, po staletí. Umělecké směřování v oblasti urbanismu klasicky charakterizoval Camillo Sitte. Jeho zásady jsou stále platné a použitelné i dnes. V současnosti Christopher Alexander a Nikos A. Salingaros definují patnáct vlastností, které má vykazovat každá kvalitní architektura i každé kvalitní město. Významné jsou také práce současného konzervativního filozofa sira Rogera Scrutona (Scruton R., 2013), který přesně pojmenovává problémy v současné architektuře, hudbě, estetice a filozofii i v současném umění. V rámci doktorského výzkumu bude rozeslán dotazník jednotlivým školám umění a architektury, který zmapuje současnou situaci související s aktivní výukou tradicionalismu nebo zájmem o něj. Tradicionalismus nabízí lépe řešený životní prostor, nadčasovost, estetickou krásu, dlouhodobou udržitelnost a trvanlivost po budoucí staletí.
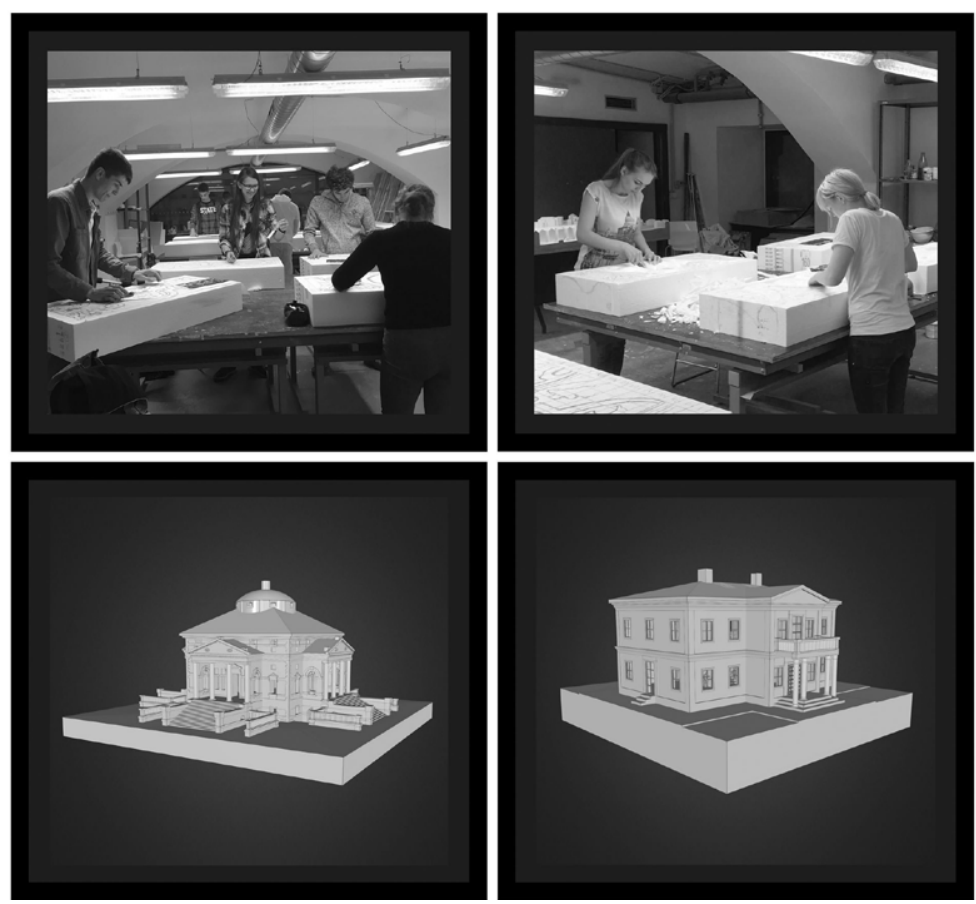

Obr. 1. Traditionalism at universities, colleges and in practice (Zdroj: archiv autora) 


\section{Použitá literatura}

ADAM, Robert. YouGov survey published this week suggests people prefer traditionally designed buildings. 2009. YouGov Poll. https://www.adamarchitecture. com/images/PDFs/YouGov\%20survey_Oct09_results\&followup.pdf

AUBIN, F. Paul, 2013. Renaissance Revit: Creating Classical Architecture with Modern Software. První vydání. Oak Lawn: G3B Press. 474 s. ISBN 978-1492976592

BEČKOVÁ, Kateřina. Administrativní budova Na Florenci včetně připojení na technickou infrastrukturu, Praha 1. Praha. 2016. Klub za starou Prahu. Čj. MHMP 1267822/2016/EIA/1014/Žá http://www.zastarouprahu.cz/webdata/922FCAA6-2352-4A40-800B-F7EE9E1544E7.pdf

CAD BLOCKS. Classical Architectural Orders. CAD - block. 2018. https://cad-block. com/217-classical-architectural-orders.html

CONGDON, Roark. Modeling Architectural Columns in Rhino. Pluralsight. 2015. https://www.pluralsight.com/courses/modeling-arch-columns-rhino-2239

DREXLER, Arthur, 1977. The Architecture of the Ecole des Beaux-Arts. První vydání. Cambridge: MIT Press. 525 s. ISBN 978-0870702440

EGBERT, Donald Drew, 1980. The Beaux-Arts Tradition in French Architecture: Illustrated by the Grands Prix de Rome. Luxusní vydání. Princeton: Princeton University Press. 240 s. ISBN 978-0691101064

FASTBRICK ROBOTICS. The Architectural Designer add-on (TAD). FBR. 2018. https://www.fbr.com.au

DIGITAL APPLICATIONS IN ARCHAEOLOGY AND CULTURAL HERITAGE. Ř́m: Istituto per le tecnologie applicate ai beni culturali (CNR ITABC). 2012. ISSN 2212-0548

GOLDBERGER, Paul, 2015. Building Art: The Life and Work of Frank Gehry. První vydání. New York: Knopf. 528 s. ISBN 978-0307701534

GRAPHISOFT. Classics modeled with Archicad - Wells Cathedral, Wells, Somerset, England. 2011. https://www.youtube.com/watch?v=5R_17GlRAsk

HARDY, Matthew, 2008. The Venice Charter Revisited: Modernism and Conservation in the Postwar World. Nové vydání. Newcastle: Cambridge Scholars Publishing. 791 s. ISBN 978-1847186881

HASSELAAR, Evert, 2008. Health risk associated with passive houses: An exploration. In: Indoor Air 2008. Copenhagen: Paper ID: 689. https://www.isiaq.org/docs/ papers/689.pdf

HEUMAN, Felix; LYHAGEN Anders. Classical architecture modelling in SketchUp. 2015. https://www.youtube.com/watch?v=Y5nEN602U4A

HOLMES, Steve. Re-Create Classical Sculptures With ZBrush. 3D Artist. 2016. https://www.3dartistonline.com/news/2016/07/re-create-classical-sculptures-with-zbrush/ 
HORÁČEK, Martin, 2013. Za krásnější svět: Tradicionalismus v architektuře 20. a 21. století. První vydání. Brno: Barrister \& Principal - VUTIUM. 448 s. G3B Press. 474 s. ISBN 978-8074850028

JOHNSON, Philip; WIGLEY, Mark, 1988. Deconstructivist Architecture. New York: The Museum of Modern Art. 104 s. ISBN 087070298X

KRIER, Léon, 1998. Architecture: Choice Or Fate. Winterbourne: Papadakis. 208 s. ISBN 978-1901092752

MOUSSAVI, Farshid; KUBO, Michael, 2006. The Function of Ornament. New York: Actar Publishers. 192 s. ISBN 978-8496540507

NAYLOR, Gillian, 1980. The Arts and Crafts Movement. Cambridge: MIT Press. 208 s. ISBN 978-0262640183

O'SKEA, Sean. Greek Pavilion Model Tutorial for Vectorworks. 2013. https://www. youtube.com/watch?v=qOGhsjRTjIo

PALLADIO, Andrea, 2002. The Four Books on Architecture. Cambridge: MIT Press. 472 s. ISBN 978-0262661331

ROWLAND, Ingrid D.; HOWE Thomas Noble, 2001. Vitruvius: Ten Books on Architecture. Cambridge: Cambridge University Press. 352 s. ISBN 978-0521002929

SALINGAROS, Nikos Angelos, 2017. Sjednocená teorie architektury: Forma, jazyk, komplexita. Brno: VUTIUM - Barrister \& Principal Publishing. 404 s. ISBN 9788074851384

SCHNABEL, Marc Aurel. Parametric Design in Architecture. In: Computer-Aided Architectural Design Futures (CAADFutures) 2007: Proceedings of the 12th International CAADFutures Conference. Dordrecht: stránky 237-250. DOI 10.1007/978-1-4020-6528-6_18. ISBN: 978-1402065279

SCRUTON, Roger. Why Beauty Matters. Londýn: BBC. 2009. https://www.bbc.co.uk/ programmes/b00p6tsd

SCRUTON, Roger, 2013. The Aesthetics of Architecture. Princeton: Princeton University Press. 320 s. ISBN 978-0691158334

SITTE, Camillo, 1995. Stavba měst podle uměleckých zásad. Brno: ÚÚR, ABF. $111 \mathrm{~s}$. ISBN 9788087318218

SMITH, George Saumarez; TERRY Francis. Classical architecture in modern times. London: TEDx Talks. 2012. https://www.youtube.com/watch?v=FgMOSVyjgQY\&vl=en

WATKIN, David, 2006. Radical Classicism: The Architecture of Quinlan Terry. První vydání. New York: Rizzoli. 208 s. ISBN 978-0847828067

WEIL, Claudia; WEIL Thomas, 2009. Geometric Ornament in Architecture, Art \& Design. Atglen: Schiffer Publishing. ISBN 978-0764333798 